\title{
Thymoquinone and curcumin modify inducible nitric oxide synthase, caspase 3, and thioredoxin immunohistochemical expression in acetaminophen hepatotoxicity
}

\author{
M. Atteya ${ }^{1}$, A.M. Ahmed ${ }^{1}$, A. AlRabiah'1, T.A. Al-Matrafi' ${ }^{1}$ M.M. Arafah², S. Al-Saggaf ${ }^{3}$,
} S.H. Shereef ${ }^{1}$, A.-A.H. Ahmed ${ }^{1}$, H.M. Alqahtani' ${ }^{1}$, R.A.T. Mohammad ${ }^{1}$

${ }^{1}$ Department of Anatomy, College of Medicine, King Saud University, Riyadh, Saudi Arabia

2Department of Pathology, College of Medicine, King Saud University, Riyadh, Saudi Arabia

${ }^{3}$ Department of Anatomy, Faculty of Medicine, King Abdul Aziz University, Jeddah, Saudi Arabia

[Received: 7 January 2019; Accepted: 22 February 2019]

Background: Acetaminophen (APAP) hepatotoxicity is characterised by an extensive oxidative stress due to depletion of glutathione (GSH), which results in massive lipid peroxidation and subsequent liver injury. The current paradigm suggests that mitochondria are the main source of reactive oxygen species (ROS), which impair mitochondrial function and are responsible for cell signalling resulting in cell death. This study was designed to compare the potential impact of thymoquinone (THQ), and/or curcumin (CURC) on liver injury induced by APAP toxicity in rats.

Materials and methods: Serum levels of alanine transaminase, aspartate transaminase, total bilirubin, and total protein were measured. In addition, liver nitric oxide (NO), malondialdehyde, reduced glutathione (GSH), and superoxide dismutase (SOD) were estimated. Moreover, these biochemical parameters were confirmed by histopathological and immunohistochemical investigations for the expression of thioredoxin, iNOS and caspase 3.

Results: Acetaminophen toxicity elevated most of the above-mentioned parameters but decreased GSH, SOD, and total protein levels. Histologically, liver sections demonstrated liver injury characterised by hepatocellular necrosis with nuclear pyknosis, karyorrhexis and karyolysis. Immunohistochemical study revealed increased expression of iNOS and caspase 3 proteins, while the thioredoxin protein expression was decreased.

Conclusions: Treatment with the THQ and CURC regulated the biochemical and histopathological alterations induced by APAP toxicity. It was concluded that the combination strategy of THQ and CURC might be considered as a potential antidote in combating liver injury induced by APAP with minimal side effects. (Folia Morphol 2019; 78, 4: 773-788)

Key words: thymoquinone, curcumin, acetaminophen, hepatotoxicity

Address for correspondence: Dr. M. Atteya, Department of Anatomy, College of Medicine, King Saud University, PO Box 2925 (28), Riyadh 11461, Saudi Arabia, tel: +966(11)4679554, Mobile +966502765609, fax +966(11)4671300, e-mail: mhasan1@ksu.edu.sa 


\section{INTRODUCTION}

Acetaminophen (APAP) hepatotoxicity is the leading cause of acute liver failure in many countries $[12,50]$. A key mechanism of the toxicity is the cytochrome P450-catalysed metabolic activation of APAP, which generates the reactive metabolite $\mathrm{N}$-acetyl-p-benzoquinone imine (NAPQI) and initiates toxicity in both rodents and humans [34]. Excessive NAPQI formation after APAP overdose depletes cellular reduced glutathione (GSH), adds proteins including mitochondrial proteins, and induces mitochondrial oxidant stress and dysfunction. This causes nuclear DNA fragmentation and necrotic cell death and a subsequent inflammatory response, including the release of pro-inflammatory cytokines and activation of immune cells [34].

In the 1980's, it was recognised that cytochrome P450-mediated drug metabolism in microsomes could generate reactive oxygen species (ROS) (mainly superoxide and hydrogen peroxide) [40]. Since APAP is also metabolised by P450 enzymes in microsomes, it was assumed that P450-mediated metabolism of APAP generated ROS in APAP hepatotoxicity, leading to subsequent lipid peroxidation and liver injury [76]. This hypothesis was mainly based on the use of inducers and inhibitors of cytochrome P450, which enhanced and attenuated APAP-induced lipid peroxidation, respectively [76]. Lipid peroxidation has been a frequently invoked mechanism in ROS-induced cell death and liver injury $[36,60,69]$. Another potential source of oxidant stress after APAP overdose is the infiltrating neutrophils. These phagocytes are the first immune cells to respond to the extensive APAP-induced necrosis [43]. However, neutrophils do not only produce superoxide and hydrogen peroxide by NADPH oxidase, but due to the presence of myeloperoxidase, these cells can generate hypochlorite. Furthermore, in contrast to Kupffer cells, neutrophils are mobile and can extravasate from sinusoids and adhere to the targeted hepatocytes to be fully activated [32]. The adherence to hepatocytes triggers a long-lasting oxidant stress in close proximity to the target, which allows oxidants such as hydrogen peroxide [33] and hypochlorous acid [26-28] to diffuse into hepatocytes and induce cell death.

Curcumin (diferuloymethane) (CURC), a polyphenol, is an active ingredient of turmeric (Curcuma longa) and is pharmacologically safe for humans and animals. CURC has many biological activities, including anti-inflammatory, antioxidant, anti-carcinogenic, anti-mutagenic, and anti-diabetic activities [14, 48, $55,70]$. The hepatoprotection of CURC has been widely acknowledged and used in traditional medicines for treatment of inflammatory conditions such as hepatitis [68]. A previous study demonstrated that CURC treatment showed significant decrease in serum transaminase, hepatic malondialdehyde (MDA), increasing hepatic GSH, and caused improvement of liver histopathology [38, 71, 82].

Thymoquinone (THQ) is the most potent component of Nigella Sativa (N. sativa) [7]. Protective effects of THQ were established in doxorubicin, carbon tetrachloride, cisplatin, ethanol and aflatoxin-induced oxidative damage. In addition, the anti-inflammatory, anti-tumoural, anti-microbial, anti-histaminic and immuno-modulatory effects of THQ have been reported. Moreover, it has been suggested that THQ may act as an antioxidant agent and prevent the membrane lipid peroxidation in hepatocytes [7]. Alsaif [6] found that THQ significantly and dose dependently prevented the ethanol-induced acute hepatotoxicity by enhancing the hepatic antioxidant activity. Kong et al. [39] suggests that THQ has protective effects against oxidative damage and liver fibrosis during the development of extrahepatic cholestasis caused by bile duct ligation. They referred the underlying mechanism to body hydroxyproline (HP) content, which reduces and maintains the balance of the oxidative-antioxidative system.

This study aimed to evaluate and compare the ameliorator property of THQ and CURC, alone or together, against acetaminophen (paracetamol)-induced biochemical, and histopathological changes.

\section{MATERIALS AND METHODS}

\section{Experimental animals and treatment}

Thirty healthy male albino rats (120-160 g) were supplied by the Experimental Animal Centre, College of Medicine, King Saud University. Animals were kept in special cages and maintained on a constant 12-h light/12-h dark cycle with air conditioning and a controlled temperature of $20-22^{\circ} \mathrm{C}$ and humidity of $60 \%$. Rats were fed a standard rat pellet chow with free access to tap water ad libitum for 1 week before the experiment for acclimatisation. Animal utilisation protocols were performed in accordance with the guidelines provided by the Experimental Animal Laboratory and approved by the Animal Care and Use Committee of the College of Medicine, King Saud University. 
After 1 week of acclimatisation, the rats were randomly divided into five groups of 6 rats each as follows:

- Group 1 (Control group): rats given normal saline;

- Group 2 (APAP group): rats given a single oral dose of APAP $750 \mathrm{mg} / \mathrm{kg}$ [84];

- Group 3 (APAP+CURC group): rats given three oral doses of CURC $200 \mathrm{mg} / \mathrm{kg}$ (purchased from Armal company), dissolved in corn oil [4];

- Group 4 (APAP+THQ group): rats given three oral doses of THQ $15 \mathrm{mg} / \mathrm{kg}$ (purchased from Sigma Chemical Co., MO, USA), dissolved in corn oil [1, 4];

- Group 5 (APAP+CURC+THQ): rats given combination of CURC and THQ in the same previous doses for each.

The first dose of CURC and/or THQ was given $24 \mathrm{~h}$ before APAP administration then the second dose was given $2 \mathrm{~h}$ after APAP administration, whereas the third dose was given $12 \mathrm{~h}$ after APAP administration. There were no mortalities or affection of health status among all the groups.

One day after APAP administration, all animals were sacrificed; blood samples were withdrawn from them and sera were separated by centrifugation at $3000 \mathrm{rpm}$ for $20 \mathrm{~min}$ and used for biochemical serum analysis. After blood collection, the livers were excised and washed using chilled saline solution. The livers were minced and homogenised in ice-cold bi-distilled water to yield $20 \%$ homogenates. The homogenates were centrifuged for $20 \mathrm{~min}$ at $3000 \mathrm{rpm}$ at $5^{\circ} \mathrm{C}$, and the supernatants were used for biochemical tissue analysis. Three livers from each group were kept in $10 \%$ buffered formalin for histopathological examination and immunohistochemistry analysis.

\section{Biochemical analysis}

Serum biochemical assays

- Serum alanine transaminase (ALT)

- Aspartate transaminase (AST)

- Total bilirubin

- Total protein

All these parameters were measured using commercial diagnostic kits from Randox Company (UK) following the manufacturer's instructions.

\section{Hepatic biochemical assays}

Lipid peroxidation (malondialdehyde [MDA]). The degree of lipid peroxidation in hepatic tissues was determined by measuring thiobarbituric acid reactive substances (TBARS) in the liver homogenate [53]. The absorbance was measured spectrophotometrically at $532 \mathrm{~nm}$.

Reduced glutathione (GSH). Reduced glutathione was determined using the method of Ellman GL based on its reaction with 5,5'-dithiobis (2-nitrobenzoic acid) to yield the yellow chromophore, 5-thio-2-nitrobenzoic acid at $412 \mathrm{~nm}$ [19].

Total nitrite concentration. Total nitrite was measured according to the method described by Moshage et al. [54] using Griess reagent (sulphanilamide and N-1-naphthylethenediamine dihydrochloride) in acidic medium.

\section{Histopathological and immunohistochemical analysis}

Liver specimens were excised and fixed in $10 \%$ buffered formalin overnight, then processed to prepare paraffin wax at $56^{\circ} \mathrm{C}$. Serial sections were cut at $4 \mu \mathrm{m}$. These sections were used for histopathological examination using haematoxylin and eosin (H\&E) stain and immunohistochemical detection of:

— thioredoxin; ab 86255;

— inducible nitric oxide synthase (iNOS); ab 15323;

- caspase 3; ab 52293.

Immunostaining of hepatic paraffin sections for detection of the abnormal immune reaction of different primary antibodies was performed using streptavidin-biotinylated horseradish peroxidase method (Novalink ${ }^{\mathrm{TM}}$ Max Polymer Detection System, Novocastra, Product No: RE7280-K, Leica Biosystems Newcastle Ltd., United Kingdom). The procedure involved the following steps: endogenous peroxidase activity was inhibited by $3 \% \mathrm{H}_{2} \mathrm{O}_{2}$ in distilled water for $10 \mathrm{~min}$, and then the sections were washed in Tris-buffered saline (TBS) (Sigma, T 5030-100 TAB, $\mathrm{PH}$ 7.6) twice for $5 \mathrm{~min}$ for each wash. Non-specific binding of antibodies was blocked by incubation with protein block for $10 \mathrm{~min}$ (Novocastra). Sections were incubated with rabbit polyclonal primary antibodies diluted 1:100 for $1 \mathrm{~h}$ at room temperature. Sections were washed in Tris buffer for twice, each for $5 \mathrm{~min}$, then incubated with biotinylated anti-rabbit IgG (Novocastra) for $30 \mathrm{~min}$. This was followed by washing in Tris buffer 2 times, each for $5 \mathrm{~min}$, and then incubated with Novolink polymer (Novocastra) for $30 \mathrm{~min}$. Then the sections were washed in Tris buffer 2 times, each for $5 \mathrm{~min}$. Peroxidase was detected with working solution of diaminobenzidine (DAB) substrate (Novocastra) for $10 \mathrm{~min}$. Finally, sections were washed in distilled water for $10 \mathrm{~min}$, nuclei were 
stained with Mayer's haematoxylin for $5 \mathrm{~min}$ and sections were mounted in DPX. For negative control sections, the same procedure was followed with the omission of incubation in primary antibodies [4].

\section{Image analysis}

High-resolution whole-slide digital scans of all stained histological sections were created with Aperio ScanScope scanner (Leica Microsystems, Germany). The digital slide images were viewed and analysed using Aperio ImageScope software (Leica Microsystems, Germany). To quantify the immunopositive reaction, five areas, each with the fixed size of $0.480 \mathrm{~mm}^{2}$, were randomly selected per section, and the colour deconvolution (colour separation) algorithm (Aperio Technologies, Inc.) was set up (by colour calibration) to detect and quantify only the brown colour of positive staining. The algorithm was then run on the selected areas to measure the percentage of the colour of interest relative to the total area of analysis. All image analysis output results were finally exported to Excel sheets and subjected to statistical analysis.

\section{Statistical analysis}

Data collected were subjected to statistical analysis using IBM SPSS Statistics version 22 software. The homogeneity of the obtained numerical data was first checked with Levene test and the homogeneity of variance assumption has been met. Analysis of variance (ANOVA) was used for an overall comparison between the study groups followed by Benferroni post-hoc test for pairwise comparisons. Differences were considered significant when $p$ was equal to or less than 0.05 .

\section{RESULTS}

Biochemical results

The results of the present study showed that APAP intoxication induced significant increase in the serum levels of total bilirubin, ALT and AST compared to the control group ( $p \leq 0.05$ ) (Tables $1-3)$. In addition, it induced significant increase in the hepatic levels of nitric oxide (NO) and MDA compared to the control group ( $p \leq 0.05$ ) (Tables 4,5 ). On the other hand, APAP intoxication resulted in significant decrease in the serum level of total protein and the hepatic levels of GSH and superoxide dismutase (SOD) compared to the control group ( $p \leq 0.05$ ) (Tables $6-8)$. Treatment with CURC or THQ, respectively, induced mild or moderate alleviation of the changes in most of the above-mentioned serum and hepatic biochemical parameters (Tables 1-8). However, treatment with combination of CURC and THQ successively induced marked alleviation of most of these biochemical parameters (Tables $1-8$ ).

Table 1. Serum levels of total bilirubin $(\mathrm{mg} / \mathrm{dL})$ in the studied groups

\begin{tabular}{lccccc}
\hline & $\begin{array}{c}\text { Group 1 } \\
\text { (Control) }\end{array}$ & $\begin{array}{c}\text { Group 2 } \\
\text { (APAP) }\end{array}$ & $\begin{array}{c}\text { Group 3 } \\
\text { (APAP+CURC) }\end{array}$ & $\begin{array}{c}\text { Group 4 } \\
\text { (APAP+TH0) }\end{array}$ & $\begin{array}{c}\text { Group 5 } \\
\text { (APAP+CURC+TH0) }\end{array}$ \\
\hline Mean \pm SE & $1.602 \pm 0.018$ & $2.526 \pm 0.038$ & $2.284 \pm 0.033$ & $1.93 \pm 0.053$ & $1.94 \pm 0.06$ \\
P1 & & $0.000^{*}$ & $0.000^{*}$ & $0.000^{*}$ & $0.000^{*}$ \\
P2 & & $0.008^{*}$ & $0.000^{*}$ & $0.000^{*}$ \\
P3 & $0.000^{*}$ & $0.008^{*}$ & & $0.000^{*}$ & $0.000^{*}$ \\
P4 & $0.000^{*}$ & $0.000^{*}$ & $0.000^{*}$ & & 1.000 \\
\hline
\end{tabular}

${ }^{*}$ Significant difference $(p \leq 0.05)$; SE — standard error; P1 — versus group 1; P2 — versus group 2; P3 — versus group 3; P4 - versus group 4; other abbreviations - see text

Table 2. Serum levels of alanine transaminase (U/L) in the studied groups

\begin{tabular}{lccccc}
\hline & $\begin{array}{c}\text { Group 1 } \\
\text { (Control) }\end{array}$ & $\begin{array}{c}\text { Group 2 } \\
\text { (APAP) }\end{array}$ & $\begin{array}{c}\text { Group 3 } \\
\text { (APAP+CURC) }\end{array}$ & $\begin{array}{c}\text { Group 4 } \\
\text { (APAP+THO) }\end{array}$ & $\begin{array}{c}\text { Group 5 } \\
\text { (APAP+CURC+THO) }\end{array}$ \\
\hline Mean \pm SE & $49.400 \pm 0.574$ & $150.400 \pm 0.608$ & $89.220 \pm 0.974$ & $68.880 \pm 0.795$ & $61.400 \pm 0.482$ \\
P1 & & $0.000^{*}$ & $0.000^{*}$ & $0.000^{*}$ & $0.000^{*}$ \\
P2 & $0.000^{*}$ & & $0.000^{*}$ & $0.000^{*}$ & $0.000^{*}$ \\
P3 & $0.000^{*}$ & $0.000^{*}$ & & $0.000^{*}$ & $0.000^{*}$ \\
P4 & $0.000^{*}$ & $0.000^{*}$ & $0.000^{*}$ & & $0.000^{*}$
\end{tabular}

${ }^{*}$ Significant difference $(\mathrm{p} \leq 0.05)$; SE — standard error; P1 — versus group 1; P2 — versus group 2; P3 - versus group 3; P4 — versus group 4; other abbreviations — see text 
Table 3. Serum levels of aspartate transaminase (U/L) in the studied groups

\begin{tabular}{lccccc}
\hline & $\begin{array}{c}\text { Group 1 } \\
\text { (Control) }\end{array}$ & $\begin{array}{c}\text { Group 2 } \\
\text { (APAP) }\end{array}$ & $\begin{array}{c}\text { Group 3 } \\
\text { (APAP+CURC) }\end{array}$ & $\begin{array}{c}\text { Group 4 } \\
\text { (APAP+THO) }\end{array}$ & $\begin{array}{c}\text { Group 5 } \\
\text { (APAP+CURC+THO) }\end{array}$ \\
\hline Mean \pm SE & $120.400 \pm 0.583$ & $246.000 \pm 1.691$ & $189.340 \pm 1.055$ & $140.420 \pm 1.476$ & $129.760 \pm 0.449$ \\
P1 & & $0.000^{*}$ & $0.000^{*}$ & $0.000^{*}$ & $0.000^{*}$ \\
P2 & $0.000^{*}$ & & $0.000^{*}$ & $0.000^{*}$ & $0.000^{*}$ \\
P3 & $0.000^{*}$ & $0.000^{*}$ & & $0.000^{*}$ & $0.000^{*}$ \\
P4 & $0.000^{*}$ & $0.000^{*}$ & $0.000^{*}$ & & $0.000^{*}$ \\
\hline
\end{tabular}

${ }^{*}$ Significant difference $(\mathrm{p} \leq 0.05)$; SE — standard error; P1 — versus group 1; P2 — versus group 2; P3 — versus group 3; P4 — versus group 4; other abbreviations — see text

Table 4. Hepatic nitric oxide $(\mathrm{mg} / \mathrm{dL})$ in the studied groups

\begin{tabular}{lccccc}
\hline & $\begin{array}{c}\text { Group 1 } \\
\text { (Control) }\end{array}$ & $\begin{array}{c}\text { Group 2 } \\
\text { (APAP) }\end{array}$ & $\begin{array}{c}\text { Group 3 } \\
\text { (APAP+CURC) }\end{array}$ & $\begin{array}{c}\text { Group 4 } \\
\text { (APAP+THO) }\end{array}$ & $\begin{array}{c}\text { Group 5 } \\
\text { (APAP+CURC+THO) }\end{array}$ \\
\hline Mean \pm SE & $0.818 \pm 0.227$ & $1.448 \pm 0.033$ & $1.414 \pm 0.027$ & $1.272 \pm 0.022$ & $0.904 \pm 0.017$ \\
P1 & & $0.000^{*}$ & $0.000^{*}$ & $0.000^{*}$ & 0.229 \\
P2 & $0.000^{*}$ & 1.000 & $0.001^{*}$ & $0.000^{*}$ \\
P3 & $0.000^{*}$ & 1.000 & & $0.006^{*}$ & $0.000^{*}$ \\
P4 & $0.000^{*}$ & $0.001^{*}$ & $0.006^{*}$ & & $0.000^{*}$ \\
\hline
\end{tabular}

${ }^{*}$ Significant difference $(\mathrm{p} \leq 0.05)$; SE — standard error; $\mathrm{P} 1$ - versus group 1; P2 - versus group 2; $\mathrm{P} 3$ - versus group 3; P4 - versus group 4; other abbreviations - see text

Table 5. Hepatic malondialdehyde $(\mathrm{mg} / \mathrm{dL})$ in the studied groups

\begin{tabular}{lccccc}
\hline & $\begin{array}{c}\text { Group 1 } \\
\text { (Control) }\end{array}$ & $\begin{array}{c}\text { Group 2 } \\
\text { (APAP) }\end{array}$ & $\begin{array}{c}\text { Group 3 } \\
\text { (APAP+CURC) }\end{array}$ & $\begin{array}{c}\text { Group 4 } \\
\text { (APAP+THO) }\end{array}$ & $\begin{array}{c}\text { Group 5 } \\
\text { (APAP+CURC+THO) }\end{array}$ \\
\hline Mean \pm SE & $80.772 \pm 0.411$ & $172.398 \pm 1.221$ & $128.252 \pm 0.819$ & $96.544 \pm 0.388$ & $98.442 \pm 0.241$ \\
P1 & & $0.000^{*}$ & $0.000^{*}$ & $0.000^{*}$ & $0.000^{*}$ \\
P2 & $0.000^{*}$ & $0.000^{*}$ & $0.000^{*}$ & $0.000^{*}$ \\
P3 & $0.000^{*}$ & $0.000^{*}$ & & $0.000^{*}$ & $0.000^{*}$ \\
P4 & $0.000^{*}$ & $0.000^{*}$ & $0.000^{*}$ & & 0.743 \\
\hline
\end{tabular}

${ }^{*}$ Significant difference $(\mathrm{p} \leq 0.05)$; $\mathrm{SE}$ - standard error; $\mathrm{P} 1$ - versus group 1; P2 - versus group 2; $\mathrm{P} 3$ - versus group 3; P4 - versus group 4; other abbreviations - see text

Table 6. Serum levels of total protein $(\mathrm{g} / \mathrm{dL})$ in the studied groups

\begin{tabular}{lccccc}
\hline & $\begin{array}{c}\text { Group 1 } \\
\text { (Control) }\end{array}$ & $\begin{array}{c}\text { Group 2 } \\
\text { (APAP) }\end{array}$ & $\begin{array}{c}\text { Group 3 } \\
\text { (APAP+CURC) }\end{array}$ & $\begin{array}{c}\text { Group 4 } \\
\text { (APAP+TH0) }\end{array}$ & $\begin{array}{c}\text { Group 5 } \\
\text { (APAP+CURC+TH0) }\end{array}$ \\
\hline Mean \pm SE & $6.25 \pm 0.057$ & $4.23 \pm 0.084$ & $5.096 \pm 0.09$ & $5.974 \pm 0.044$ & $6.252 \pm 0.046$ \\
P1 & & $0.000^{*}$ & $0.000^{*}$ & 0.087 & 1.000 \\
P2 & $0.000^{*}$ & $0.000^{*}$ & $0.000^{*}$ & $0.000^{*}$ \\
P3 & $0.000^{*}$ & $0.000^{*}$ & & $0.000^{*}$ & $0.000^{*}$ \\
P4 & 0.087 & $0.000^{*}$ & $0.000^{*}$ & & 0.083 \\
\hline
\end{tabular}

${ }^{*}$ Significant difference $(\mathrm{p} \leq 0.05)$; SE — standard error; P1 — versus group 1; P2 — versus group 2; P3 — versus group 3; P4 — versus group 4; other abbreviations — see text

\section{Histopathological results}

H\&E-stained sections of liver from control rats showed normal hepatic architecture with normal hepatocytes with intact cell margins and normal nu- clei, normal central veins with intact endothelium, and normal hepatic blood sinusoids (Fig. 1A).

$\mathrm{H} \& \mathrm{E}$-stained sections of liver from rats after administration of APAP showed extensive centrilobular 
Table 7. Hepatic reduced glutathione $(\mathrm{mg} / \mathrm{dL})$ in the studied groups

\begin{tabular}{lccccc}
\hline & $\begin{array}{c}\text { Group 1 } \\
\text { (Control) }\end{array}$ & $\begin{array}{c}\text { Group 2 } \\
\text { (APAP) }\end{array}$ & $\begin{array}{c}\text { Group 3 } \\
\text { (APAP+CURC) }\end{array}$ & $\begin{array}{c}\text { Group 4 } \\
\text { (APAP+THO) }\end{array}$ & $\begin{array}{c}\text { Group 5 } \\
\text { (APAP+CURC+TH0) }\end{array}$ \\
\hline Mean \pm SE & $0.460 \pm 0.013$ & $0.240 \pm 0.019$ & $0.284 \pm 0.019$ & $0.357 \pm 0.016$ & $0.405 \pm 0.006$ \\
P1 & & $0.000^{*}$ & $0.000^{*}$ & $0.001^{*}$ & 0.226 \\
P2 & $0.000^{*}$ & 0.592 & $0.000^{*}$ & $0.000^{*}$ \\
P3 & $0.000^{*}$ & 0.592 & & $0.037^{*}$ & $0.000^{*}$ \\
P4 & $0.001^{*}$ & $0.000^{*}$ & $0.037^{*}$ & & 0.390 \\
\hline
\end{tabular}

${ }^{*}$ Significant difference $(\mathrm{p} \leq 0.05)$; SE — standard error; P1 — versus group 1; P2 — versus group 2; P3 — versus group 3; P4 — versus group 4; other abbreviations — see text

Table 8. Hepatic superoxide dismutase $(\mathrm{U} / \mathrm{mL})$ in the studied groups

\begin{tabular}{lccccc}
\hline & $\begin{array}{c}\text { Group 1 } \\
\text { (Control) }\end{array}$ & $\begin{array}{c}\text { Group 2 } \\
\text { (APAP) }\end{array}$ & $\begin{array}{c}\text { Group 3 } \\
\text { (APAP+CURC) }\end{array}$ & $\begin{array}{c}\text { Group 4 } \\
\text { (APAP+TH0) }\end{array}$ & $\begin{array}{c}\text { Group 5 } \\
\text { (APAP+CURC+TH0) }\end{array}$ \\
\hline Mean \pm SE & $6.764 \pm 0.062$ & $3.816 \pm 0.041$ & $4.392 \pm 0.143$ & $6.216 \pm 0.042$ & $6.49 \pm 0.067$ \\
P1 & & $0.000^{*}$ & $0.000^{*}$ & $0.001^{*}$ & 0.256 \\
P2 & $0.000^{*}$ & & $0.001^{*}$ & $0.000^{*}$ & $0.000^{*}$ \\
P3 & $0.000^{*}$ & $0.001^{*}$ & & $0.000^{*}$ & $0.000^{*}$ \\
P4 & 0.256 & $0.000^{*}$ & $0.000^{*}$ & & 0.256 \\
\hline
\end{tabular}

${ }^{*}$ Significant difference $(\mathrm{p} \leq 0.05)$; SE — standard error; P1 — versus group 1; P2 — versus group 2; P3 — versus group 3; P4 — versus group 4; other abbreviations — see text

coagulative necrosis with patches of mononucleated inflammatory cellular infiltration, cytoplasmic hypereosinophilia, considerable sinusoidal dilatation and congestion, and central vein congestion with endothelial disruption. Disappearance of necrotic hepatocytes leaving empty areas and small foci of mild inflammatory reaction was observed. Necrotic hepatocytes revealed nuclear changes including pyknosis, karyorrhexis, and karyolysis (Fig. 1B).

H\&E-stained sections of liver from rats after administration of APAP and CURC showed moderate liver injury with moderate sinusoidal dilatation and congestion (Fig. 1C). H\&E-stained sections of liver from rats after administration of APAP and THQ showed mild liver injury with mild sinusoidal dilatation and congestion (Fig. 1D). H\&E-stained sections of liver from rats after administration of APAP in conjunction with CURC and THQ revealed normal lobular architecture and hepatic sinusoids with intact hepatocytes (Fig. 1E).

\section{Immunohistochemical study}

Liver sections immunostained with anti-thioredoxin antibody (Table 9) expressed very strong immunoreactivity in the cytoplasm of hepatocytes of control rats (Fig. 2A). However, cytoplasm of hepatocytes of APAP group (Fig. 2B) and APAP-CURC group (Fig. 2C) revealed weak immunoreactivity for thioredoxin. APAP-THQ showed moderate immunoreactivity for thioredoxin in cytoplasm of hepatocytes (Fig. 2D). Co-administration of both CURC and THQ after administration of APAP (APAP+CURC+THQ group) induced strong immunoreactivity for thioredoxin in cytoplasm of hepatocytes (Fig. 2E).

Immunohistochemical staining for iNOS was performed to determine the distribution and intensity of iNOS protein expression in the liver sections of rats in different groups (Table 10). The control group showed no iNOS expression in the hepatocytes (Fig. 3A). Liver sections from rats that received APAP showed strong iNOS immunoreactivity in the cytoplasm of hepatocytes in centrilobular zone and very strong iNOS immunoreactivity in all Kupffer cells (Fig. 3B). Administration of APAP with CURC induced moderate immunoreactivity in the cytoplasm of hepatocytes, while Kupffer cells showed strong iNOS immunoreactivity (Fig. 3C). Administration of APAP with THQ revealed mild, unevenly distributed iNOS immunoreactivity in the cytoplasm of hepatocytes with moderate immunoreactivity in Kupffer cells (Fig. 3D). On the other hand, co-administration of both CURC and THQ after receiving APAP induced no cytoplasmic iNOS expression in both hepatocytes and Kupffer cells (Fig. 3E). 

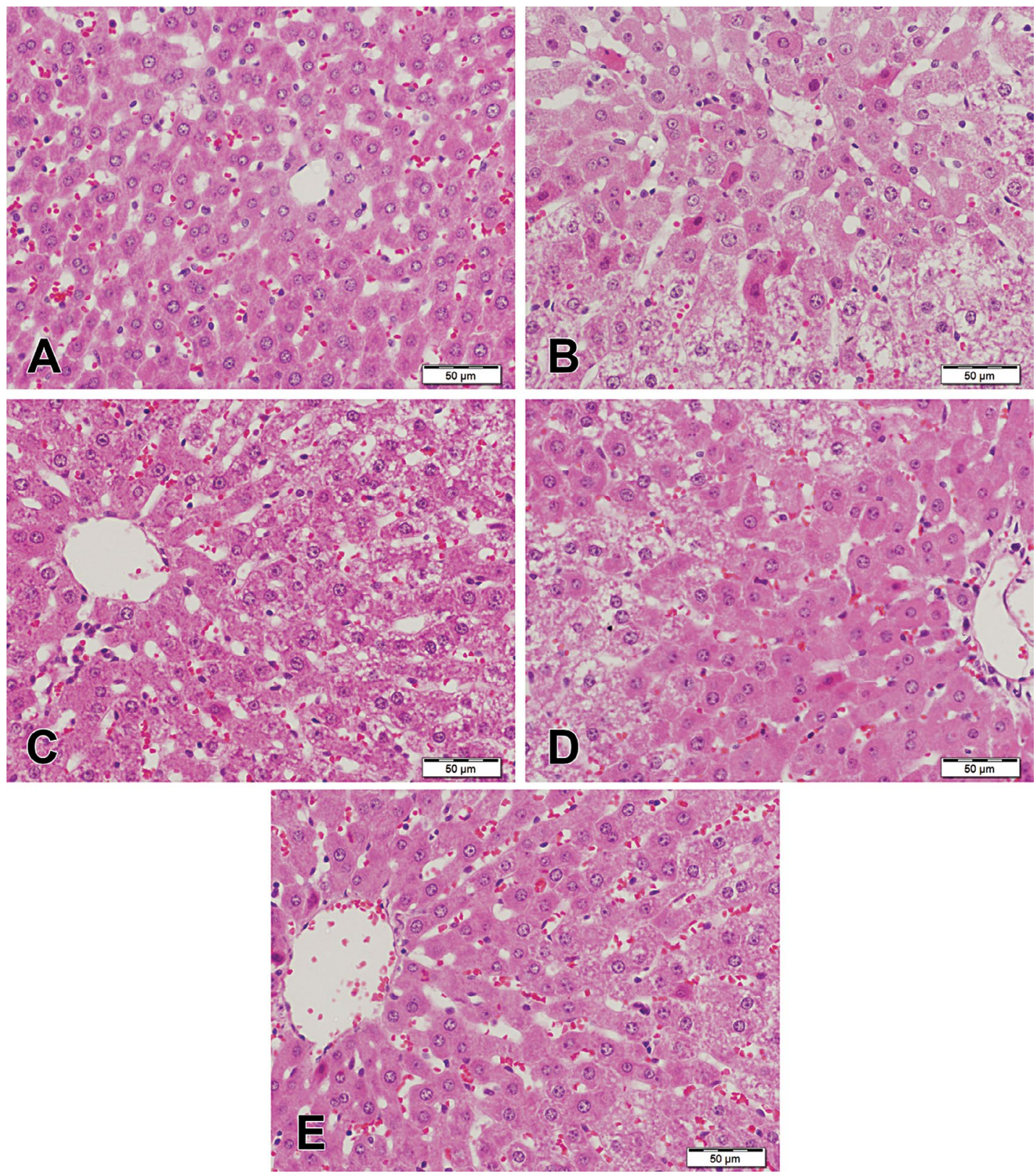

Figure 1. Representative photomicrographs of liver sections stained with H\&E; A. From control rat showing normal hepatic architecture; B. From a rat that received acetaminophen (APAP) showing severe hepatic damage with hepatocellular necrosis, cytoplasmic hypereosinophilia, marked sinusoidal dilatation and congestion with disruption of central vein endothelium; $\mathbf{C}$. From a rat that received APAP and curcumin (CURC) showing moderate liver injury; D. From a rat that received APAP and thymoquinone (THO) showing mild liver injury; E. From a rat that received APAP and combination of CURC and THO showing apparently normal liver architecture. Scale bars $=50 \mu \mathrm{m}$.

Caspase-immunoreactive cells in liver sections (Table 11) from control rats were completely negative (Fig. 4A). However, caspase immunoreactivity was very strongly positive in both cytoplasm and nuclei of numerous hepatocytes in liver sections from rats that received APAP (Fig. 4B). Administration of CURC in rats that received APAP induced strong caspase immunoreactivity in both cytoplasm and nuclei of many hepatocytes in liver sections (Fig. 4C). Administration of THQ in rats that received APAP induced moderate caspase immunoreactivity in both cytoplasm and nuclei of many hepatocytes (Fig. 4D). On the other hand, co-administration of both CURC and THQ in rats that received APAP markedly reduced caspase immunoreactivity to be mild and restricted to the cytoplasm of many hepatocytes, while the nuclei were not stained (Fig. 4E). 

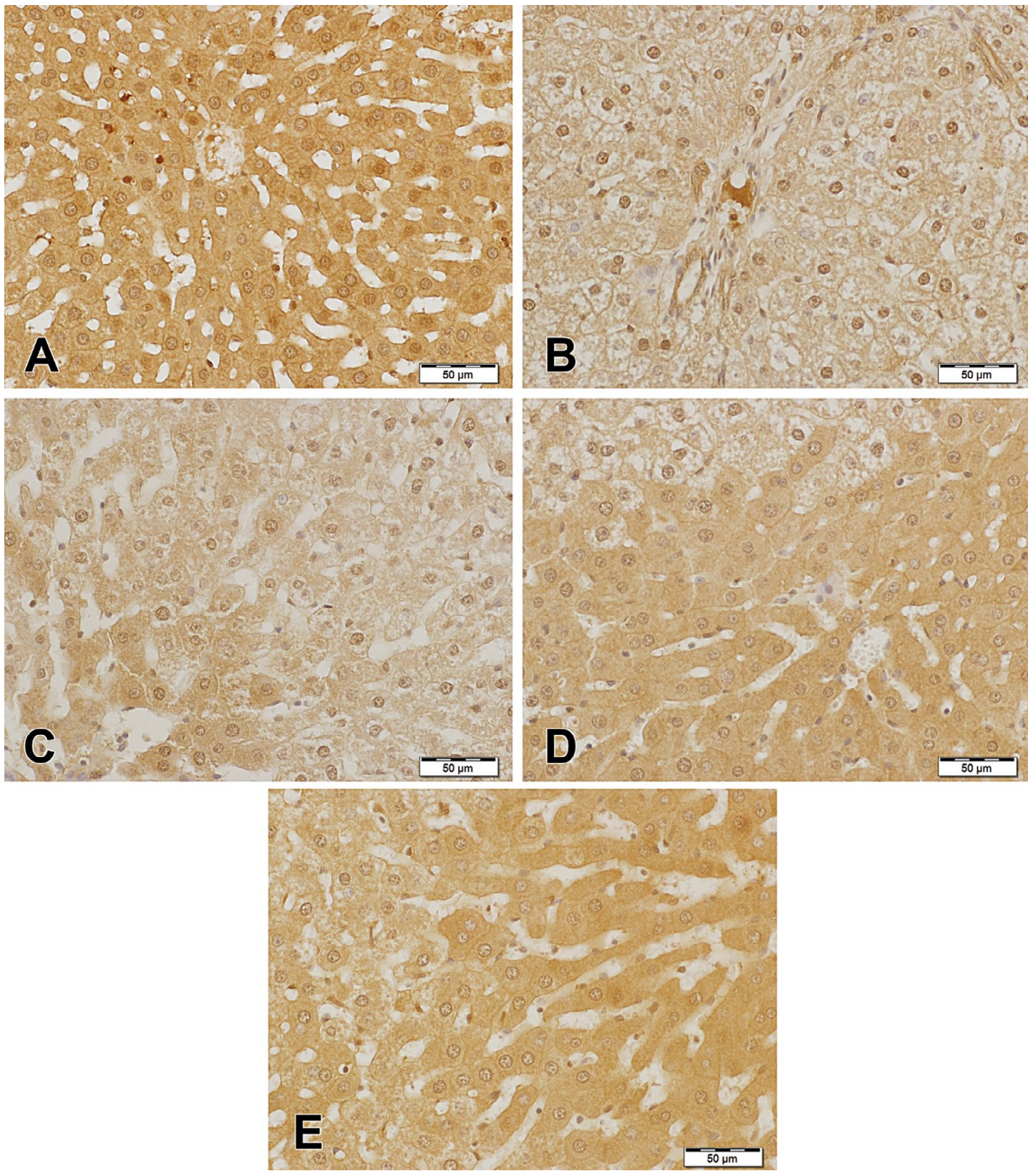

Figure 2. Representative photomicrographs of thioredoxin-immunostained liver sections; A. From control rat showing very strong immunoreactivity in the cytoplasm of hepatocytes; B. From a rat that received acetaminophen (APAP) showing weak immunoreactivity; C. From a rat that received APAP and curcumin (CURC) showing weak immunoreactivity; D. From a rat that received APAP and thymoquinone (TH0) showing moderate immunoreactivity; E. From a rat that received APAP and combination of CURC and THO showing strong immunoreactivity. Scale bars $=50 \mu \mathrm{m}$.

Table 9. Thioredoxin expression (area \%) in the studied groups

\begin{tabular}{lccccc}
\hline & $\begin{array}{c}\text { Group 1 } \\
\text { (Control) }\end{array}$ & $\begin{array}{c}\text { Group 2 } \\
\text { (APAP) }\end{array}$ & $\begin{array}{c}\text { Group 3 } \\
\text { (APAP+CURC) }\end{array}$ & $\begin{array}{c}\text { Group 4 } \\
\text { (APAP+TH0) }\end{array}$ & $\begin{array}{c}\text { Group 5 } \\
\text { (APAP+CURC+TH0) }\end{array}$ \\
\hline Mean \pm SE & $14.094 \pm 1.44$ & $0.290 \pm 0.025$ & $0.745 \pm 0.069$ & $2.193 \pm 0.184$ & $6.818 \pm 0.306$ \\
P1 & & $0.000^{*}$ & $0.000^{*}$ & $0.000^{*}$ & $0.000^{*}$ \\
P2 & $0.000^{*}$ & 1.000 & 0.557 & $0.000^{*}$ \\
P3 & $0.000^{*}$ & 1.000 & & 1.000 & $0.000^{*}$ \\
P4 & $0.000^{*}$ & 0.557 & 1.000 & & $0.001^{*}$ \\
\hline
\end{tabular}

${ }^{*}$ Significant difference $(p \leq 0.05)$; SE — standard error; P1 - versus group 1; P2 - versus group 2; P3 - versus group 3; P4 - versus group 4; other abbreviations - see text 

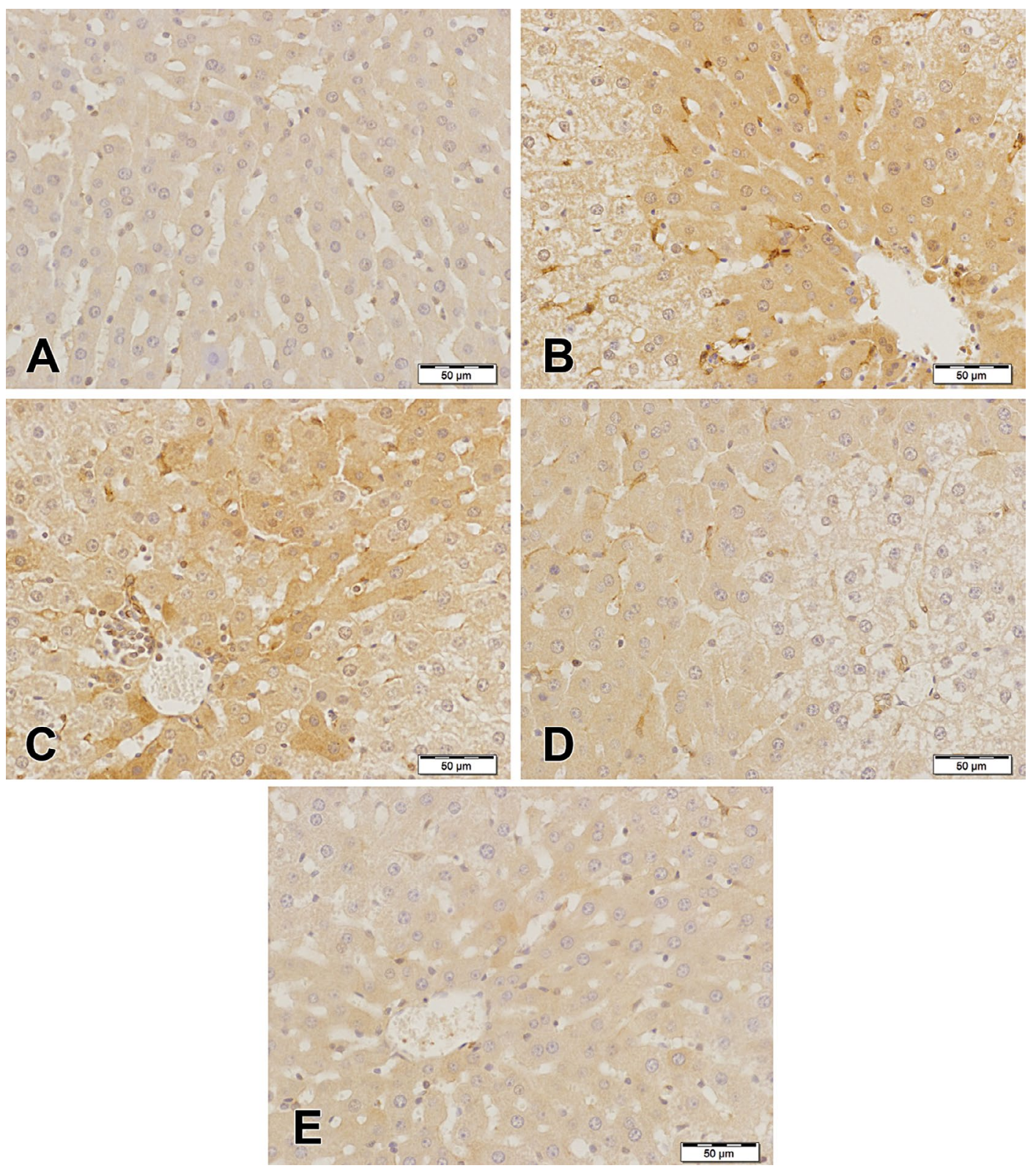

Figure 3. Representative photomicrographs of inducible nitric oxide synthase (iNOS)-immunostained liver sections; A. From control rat showing no iNOS immunoreactivity; B. From a rat that received acetaminophen (APAP) showing strong immunoreactivity in the cytoplasm of hepatocytes of the centrilobular zone and very intense immunoreactivity in Kupffer cells; C. From a rat that received APAP and curcumin (CURC) showing moderate immunoreactivity in the cytoplasm of hepatocytes and strong immunoreactivity in Kupffer cells; $\mathbf{D}$. From a rat that received APAP and thymoquinone (THO) showing mild unevenly distributed immunoreactivity in the cytoplasm of hepatocytes and moderate immunoreactivity in Kupffer cells; E. From a rat that received APAP and combination of CURC and THO showing immunoreactivity almost similar to that of the control section. Scale bars $=50 \mu \mathrm{m}$.

Table 10. Inducible nitric oxide synthase expression (area \%) in the studied groups

\begin{tabular}{lccccc}
\hline & $\begin{array}{c}\text { Group 1 } \\
\text { (Control) }\end{array}$ & $\begin{array}{c}\text { Group 2 } \\
\text { (APAP) }\end{array}$ & $\begin{array}{c}\text { Group 3 } \\
\text { (APAP+CURC) }\end{array}$ & $\begin{array}{c}\text { Group 4 } \\
\text { (APAP+THO) }\end{array}$ & $\begin{array}{c}\text { Group 5 } \\
\text { (APAP+CURC+THO) }\end{array}$ \\
\hline Mean \pm SE & $0.011 \pm 0.002$ & $1.075 \pm 0.059$ & $0.845 \pm 0.071$ & $0.154 \pm 0.034$ & $0.066 \pm 0.010$ \\
P1 & & $0.000^{*}$ & $0.000^{*}$ & 0.336 & 1.000 \\
P2 & $0.000^{*}$ & & $0.015^{*}$ & $0.000^{*}$ & $0.000^{*}$ \\
P3 & $0.000^{*}$ & $0.015^{*}$ & & $0.000^{*}$ & $0.000^{*}$ \\
P4 & 0.336 & $0.000^{*}$ & $0.000^{*}$ & & 1.000 \\
\hline
\end{tabular}

${ }^{*}$ Significant difference $(\mathrm{p} \leq 0.05)$; SE — standard error; P1 — versus group 1; P2 — versus group 2; P3 — versus group 3; P4 — versus group 4; other abbreviations — see text 

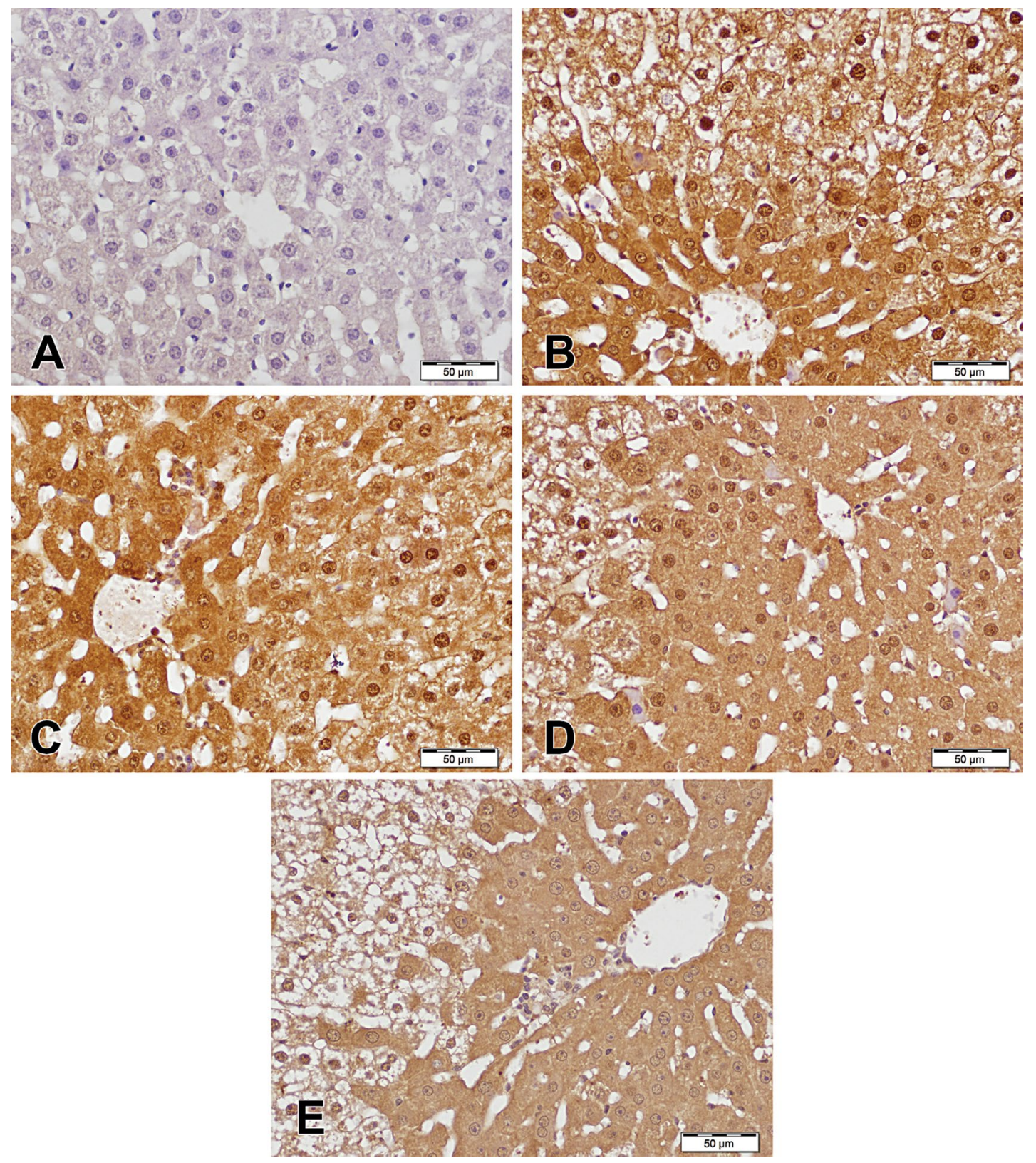

Figure 4. Representative photomicrographs of caspase-immunostained liver sections; A. From control rat showing no immunoreactivity; B. From a rat that received acetaminophen (APAP) showing strong immunoreactivity in both cytoplasm and nuclei of hepatocytes; C. From a rat that received APAP and curcumin (CURC) showing strong immunoreactivity in both cytoplasm and nuclei of hepatocytes; $\mathbf{D}$. From a rat that received APAP and thymoquinone (THO) showing moderate immunoreactivity in both cytoplasm and nuclei of hepatocytes; E. From a rat that received APAP and combination of CURC and THO showing mild immunoreactivity mainly in the cytoplasm of hepatocytes. Scale bars $=50 \mu \mathrm{m}$.

Table 11. Caspase expression (area \%) in the studied groups

\begin{tabular}{lccccc}
\hline & $\begin{array}{c}\text { Group 1 } \\
\text { (Control) }\end{array}$ & $\begin{array}{c}\text { Group 2 } \\
\text { (APAP) }\end{array}$ & $\begin{array}{c}\text { Group 3 } \\
\text { (APAP+CURC) }\end{array}$ & $\begin{array}{c}\text { Group 4 } \\
\text { (APAP+THO) }\end{array}$ & $\begin{array}{c}\text { Group 5 } \\
\text { (APAP+CURC+TH0) }\end{array}$ \\
\hline Mean \pm SE & $2.313 \pm 0.162$ & $27.13 \pm 0.641$ & $17.908 \pm 1.071$ & $10.244 \pm 0.374$ & $5.583 \pm 0.647$ \\
P1 & & $0.000^{*}$ & $0.000^{*}$ & $0.000^{*}$ & $0.021^{*}$ \\
P2 & $0.000^{*}$ & & $0.000^{*}$ & $0.000^{*}$ & $0.000^{*}$ \\
P3 & $0.000^{*}$ & $0.000^{*}$ & & $0.000^{*}$ & $0.000^{*}$ \\
P4 & $0.000^{*}$ & $0.000^{*}$ & $0.000^{*}$ & & $0.001^{*}$ \\
\hline
\end{tabular}

${ }^{*}$ Significant difference $(p \leq 0.05)$; SE — standard error; P1 — versus group 1; P2 — versus group 2; P3 — versus group 3; P4 — versus group 4; other abbreviations — see text 


\section{DISCUSSION}

The liver is the largest gland in the human body and is a unique organ anatomically located to serve its dual role in metabolic and biochemical transformation reactions. The vulnerability of the liver to injury is a function of its anatomical proximity to the blood supply and digestive tract and to its ability to concentrate and bio-transform xenobiotics [56]. Drugs, or their active metabolites, may have a direct toxic effect or induce an immune reaction to cellular proteins. Direct effects lead to predictable, dose-dependent toxicity [20]. Intoxication by APAP is among the most frequent causes of acute liver failure [3] and is widely used as a model of liver damage $[37,51$, 74]. Clinically fulminant APAP hepatotoxicity is manifested as confluent centrilobular coagulative necrosis, hydropic vacuolisation and macrophage infiltration $[16,49,63,66]$. Our histopathological findings are in accordance with the above-mentioned studies.

Prescott [64] reported that a dramatic increase in serum ALT and AST levels, mild hyperbilirubinemia, and increased prothrombin time resulted from the biochemical changes after APAP administration. Moreover, the formation of superoxide and NO causes hepatotoxicity, which is contributed by hepatic macrophages via different mechanisms [52]. These results are in accordance with those of the current work as APAP administration induced an elevation of liver biomarker enzymes such as ALT and AST, while treatment with CURC and/or THQ alleviated these altered parameters. Our results are supported by those of Aycan et al. [7] who reported that co-administration of APAP with THQ led to decrease of serum ALT and AST levels compared to those of the APAP treated group. In our study, adding CURC augmented the therapeutic effect of THQ leading to alleviation of the altered biochemical parameters and most of the histopathological changes.

In this study, histopathological analysis revealed a significant liver injury with a high dose of APAP where THQ and CURC treatment significantly lowered liver injury. Treatment with an overdose of APAP in rats was associated with extensive centrilobular coagulative necrosis of hepatocytes, destruction of endothelium, dilatation of sinusoids with mononuclear inflammatory cellular infiltration. The nuclei exhibited karyolysis, pyknosis and karyorrhexis. These findings were confirmed by the very strong positive immunoreaction for caspase in both nuclei and cytoplasm of numerous hepatocytes in the liver sections of APAP group. These results were similar to those observed previously in mice [11,62] and rats [86]. Acetaminophen induced histopathological changes starting in the centrilobular zone and increasing in severity and distribution over time [67]. These findings were confirmed by the ultrastructural changes including proliferation, dilatation, and fragmentation of endoplasmic reticulum and Golgi apparatus, in addition to the appearance of giant mitochondria with pleomorphism, paracrystalline inclusions, and dense matrix granules [49]. Necrosis may predominantly involve a particular liver zone because the enzymes involved in drug metabolism are often zonally distributed or because toxicity depends on the oxygen gradient across liver zones. The clinical manifestations of necrosis depend on its extent and duration [49]. In hepatic venular lesions, there was direct acute or chronic injury to the venular endothelium and zone 3 hepatocytes, which coincided with Farmer and Brind [20] findings.

The generation of NO from L-arginine and molecular oxygen has been proposed to mediate or modulate cellular damage in several organs, including the brain, kidneys, and liver $[8,10,45,78,83]$. NO is a gaseous free radical produced mainly by the NO synthase (NOS) family of enzymes. The isoforms of NOS are subdivided into three basic categories: endothelial NOS, neuronal NOS and iNOS, all of which are encoded by separate genes and, therefore, differently regulated. Unlike endothelial NOS and neuronal NOS, iNOS is not expressed constitutively, but is expressed in most cell types given the appropriate stimulatory conditions, which include infection, cytokines, mechanical injury, and hypoxia [79]. In healthy livers, iNOS is not thought to be expressed constitutively. However, it is readily upregulated in the liver under a number of disease conditions, including ischaemia-reperfusion injury, hepatic fibrosis, cirrhosis, and regeneration $[31,44,72,75,80,81]$. iNOS is also upregulated in vitro in hepatocytes and Kupffer cells in response to endotoxins and cytokines alone or in combination $[13,15,21,24,58]$. Our results showed marked increase of iNOS immunoreactivity in APAP treated group especially in cells suffering from degenerative changes. The availability of specific antibodies directed against iNOS has prompted attempts to understand their cellular distribution in the liver, and how that may affect the pathogenesis of liver dysfunction [13, 23, 77]. Gardner et al. [22] reported that toxic doses of APAP to rats induced hepatic- iNOS in the centrilobular hepatocytes. The development 
of toxicity is correlated with the expression of iNOS. APAP-administration induced profound elevation of NO production and oxidative stress, as evidenced by increasing lipid peroxidation level, reducing SOD activity and depleting intracellular GSH level in liver and kidney. Administration of THQ lowered iNOS immune reaction but adding THQ to CURC markedly depleted most of iNOS immune reaction.

Depletion of reduced glutathione as noticed in our study in APAP group caused an increased oxidative stress response (decreased detoxification of reactive oxygen and nitrogen species), possibly associated with alterations in calcium metabolism [29]. Then initiation of signal transduction responses and mitochondrial permeability transition, with loss of mitochondrial membrane potential lead to the loss of ability of the hepatocyte mitochondria to produce adenosine triphosphate, which is considered the most important event causing necrosis [57]. In addition, there are a number of modulators of inflammatory responses that can alter the severity of liver injury following the initiation of toxicity $[41,42]$. The interactions of these mediators with each other and the interplay of the immune cells that produce them will help to elucidate the significance of their roles in APAP toxicity [29]. Apoptotic responses as seen in many liver cells occur in conjunction with these inflammatory events $[2,18]$. These findings could explain the biochemical results of our study especially that related to ROS such as MDA and SOD. We found that combination of CURC and THQ attenuated oxidative stress by increasing the content of hepatic reduced glutathione, leading to the reduction in the level of lipid hydroperoxide (MDA) and the increase in the level of SOD.

Nagi et al. [59] reported protective effects on the prophylactic use of orally administered THQ in APAP-induced hepatotoxicity via antioxidant mechanisms. Our study is one of the early studies in literature that investigates the therapeutical effects of THQ alone or in combination with CURC after APAP overdose exposure. In our study, we have shown a remarkable reduction in APAP-induced ALT, AST levels, oxidative stress, and tissue damage. THQ (TQ; 2-isopropyl-5-methyl-1,4-benzoquinone) is the bioactive component of $\mathrm{N}$. sativa seeds and it has various pharmacological effects [5]. It is reported that THQ possesses strong antioxidant properties and protects several organs against oxidative damage induced by free radical-generating agents $[9,30,59]$. In this study, APAP administration induced significantly high
MDA levels compared to the control group. Several studies showed $40-120 \%$ elevated MDA levels compared to the control [59]. This finding correlated with the findings of previous studies. Antioxidant enzymes like SOD and GSH-Px are important for the elimination of ROS. It has been suggested that the tissue levels of SOD and GSH-Px may reflect ROS levels [9]. In addition, MDA levels can be a reliable indicator of lipid peroxidation and oxidative stress [73]. Thus, ROS can be evaluated indirectly with the determination of MDA and the levels of antioxidant enzyme activities like SOD or GSH-Px in tissue [17]. APAP-induced hepatotoxicity resulted in elevated superoxide and hydrogen peroxide levels and decreased GSH/GSSG ratio $[25,46]$. As a consequence of impairment in antioxidant defines systems, ROS and lipid peroxidation increase. Papackova et al. [61] demonstrated an increase in MDA in APAP-induced hepatic damage. In our study, the increase of MDA in liver tissue has improved in the rats given APAP as a result of THQ and CURC treatment $(p=0.001)$. This decrease in the level of MDA suggests that THQ and CURC may be effective in the prevention of lipid peroxidation. Similar studies have shown the protective effect of THQ in carbon tetrachloride-induced hepatotoxicity via the prevention of lipid peroxidation [35]. Another interesting finding in our study is the correlated MDA levels in both APAP with combination of THQ and CURC compared to control group. SOD is the major antioxidant enzyme reducing superoxide [65]. We found similar SOD levels in the control, THQ, and THQ groups indicating that THQ has a protective effect on oxidative stress. In our study, SOD levels in the APAP group decreased in association with increased free radicals.

Thioredoxin (Trx) system, consisting of Trx, thioredoxin reductase (TrxR) and $\operatorname{NADP}(H)$, is present in all living cells. TrxR catalyses the reduction of Trx by NADPH. Mammalian TrxR is a selenoprotein with ROS scavenging ability [85]. Recently, Lu and Holmgren [47] reported that inhibition of TrxR results in decreased activity of enzymes dependent on thioredoxin and reduced scavenging of ROS. This can lead to oxidative stress, apoptosis, and necrosis [47]. In this study, rats given APAP showed marked decrease of Trx immune reaction, which was restored by administration of CURC and THQ together.

\section{Clinical implication}

The combination of THQ and CURC may be considered as a safe prophylactic and therapeutic agent in APAP toxicity. 


\section{Limitations of the study}

The fact that we did neither use different doses of APAP nor a recovery group could be regarded as a limitation of our study. However, we preferred to focus on the toxic dose of the drug.

\section{CONCLUSIONS}

We have shown the therapeutic effect of the combination of THQ and CURC in terms of the regulation of antioxidant activity in APAP-induced hepatotoxicity. Therefore, this combination may be considered as a safe prophylactic and therapeutic agent in APAP toxicity.

\section{Acknowledgements}

The authors extend their appreciation to the Deanship of Scientific Research at King Saud University for funding this work through research group No. (RGP-1438-030).

\section{REFERENCES}

1. Abukhader MM. The effect of route of administration in thymoquinone toxicity in male and female rats. Indian J Pharm Sci. 2012; 74(3): 195-200, doi: 10.4103/0250474X.106060, indexed in Pubmed: 23440704.

2. Adams ML, Pierce RH, Vail ME, et al. Enhanced acetaminophen hepatotoxicity in transgenic mice overexpressing BCL-2. Mol Pharmacol. 2001; 60(5): 907-915, doi: 10.1124/ mol.60.5.907, indexed in Pubmed: 11641418.

3. Ahn B. Acetaminophen-Induced Acute Liver Failure. J Korean Med Assoc. 2006; 49(9): 846, doi: 10.5124/ jkma.2006.49.9.846.

4. Al-Rasheed NM, Attia HA, Mohamad RA, et al. Aqueous Date Flesh or Pits Extract Attenuates Liver Fibrosis via Suppression of Hepatic Stellate Cell Activation and Reduction of Inflammatory Cytokines, Transforming Growth Factor- $\beta 1$ and Angiogenic Markers in Carbon Tetrachloride-Intoxicated Rats. Evid Based Complement Alternat Med. 2015; 2015: 247357, doi: 10.1155/2015/247357, indexed in Pubmed: 25945106.

5. Ali BH, Blunden G. Pharmacological and toxicological properties of Nigella sativa. Phytother Res. 2003; 17(4): 299-305, doi: 10.1002/ptr.1309, indexed in Pubmed: 12722128.

6. Alsaif MA. Effect of Thymoquinone on Ethanol-Induced Hepatotoxicity in Wistar Rats. J Med Sci. 2007; 7(7): 1164-1170, doi: 10.3923/jms.2007.1164.1170.

7. Aycan IÖ, Tüfek A, Tokgöz O, et al. Thymoquinone treatment against acetaminophen-induced hepatotoxicity in rats. Int J Surg. 2014; 12(3): 213-218, doi: 10.1016/j. ijsu.2013.12.013, indexed in Pubmed: 24389315.

8. Bank N, Aynedjian HS, Qiu JH, et al. Renal nitric oxide synthases in transgenic sickle cell mice. Kidney Int. 1996; 50(1): 184-189, doi: 10.1038/ki.1996.301, indexed in Pubmed: 8807587.
9. Bayrak O, Bavbek N, Karatas OF, et al. Nigella sativa protects against ischaemia/reperfusion injury in rat kidneys. Nephrol Dial Transplant. 2008; 23(7): 2206-2212, doi: 10.1093/ndt/gfm953, indexed in Pubmed: 18211980.

10. Billiar T. The delicate balance of nitric oxide and superoxide in liver pathology. Gastroenterology. 1995; 108(2): 603-605, doi: 10.1016/0016-5085(95)90093-4.

11. Blazka ME, Elwell MR, Holladay SD, et al. Histopathology of acetaminophen-induced liver changes: role of interleukin 1 alpha and tumor necrosis factor alpha. Toxicol Pathol. 1996; 24(2): 181-189, doi: 10.1177/019262339602400 206, indexed in Pubmed: 8992608.

12. Budnitz DS, Lovegrove MC, Crosby AE. Emergency department visits for overdoses of acetaminophen-containing products. Am J Prev Med. 2011; 40(6): 585-592, doi: 10.1016/j.amepre.2011.02.026, indexed in Pubmed: 21565648.

13. Buttery LD, Evans TJ, Springall DR, et al. Immunochemical localization of inducible nitric oxide synthase in endotoxin-treated rats. Lab Invest. 1994; 71(5): 755-764, indexed in Pubmed: 7526041.

14. Cerný D, Lekić $N$, Váňová $K$, et al. Hepatoprotective effect of curcumin in lipopolysaccharide/-galactosamine model of liver injury in rats: relationship to $\mathrm{HO}-1 / \mathrm{CO}$ antioxidant system. Fitoterapia. 2011; 82(5): 786-791, doi: 10.1016/j. fitote.2011.04.003, indexed in Pubmed: 21545828.

15. Coffey BJ, Biederman J, Geller DA, et al. The course of Tourette's disorder: a literature review. Harv Rev Psychiatry. 2000; 8(4): 192-198, indexed in Pubmed: 11038344.

16. Dixon MF, Nimmo J, Prescott LF. Experimental paracetamol-induced hepatic necrosis: A histopathological study. J Pathol. 1971; 103(4): 225-229, doi: 10.1002/ path. 1711030404.

17. Ebru Uz, Burak Uz, Yusuf S, et al. Cardioprotective effects of Nigella sativa oil on cyclosporine A-induced cardiotoxicity in rats. Basic Clin Pharmacol Toxicol. 2008; 103(6): 574-580, doi: 10.1111/j.1742-7843.2008.00313.x, indexed in Pubmed: 18801029.

18. El-Hassan H, Anwar K, Macanas-Pirard P, et al. Involvement of mitochondria in acetaminophen-induced apoptosis and hepatic injury: roles of cytochrome c, Bax, Bid, and caspases. Toxicol Appl Pharmacol. 2003; 191(2): 118-129, doi: 10.1016/s0041-008x(03)00240-0, indexed in Pubmed: 12946648 .

19. Ellman GL. Tissue sulfhydryl groups. Arch Biochem Biophys. 1959; 82(1): 70-77, doi: 10.1016/0003-9861(59)90090-6, indexed in Pubmed: 13650640.

20. Farmer A, Brind A. Drug-induced liver injury. Medicine. 2011; 39(9): 536-540, doi: 10.1016/j.mpmed.2011.06.003.

21. Forstermann U, Closs El, Pollock JS, et al. Nitric oxide synthase isozymes. Characterization, purification, molecular cloning, and functions. Hypertension. 1994; 23(6, Pt 2): 1121-1131, doi: 10.1002/hep.510270316, indexed in Pubmed: 7515853.

22. Gardner CR, Heck DE, Yang CS, et al. Role of nitric oxide in acetaminophen-induced hepatotoxicity in the rat. Hepatology. 1998; 27(3): 748-754, doi: 10.1002/hep.510270316, indexed in Pubmed: 9500703.

23. Geller DA, Nussler AK, Di Silvio M, et al. Cytokines, endotoxin, and glucocorticoids regulate the expression of 
inducible nitric oxide synthase in hepatocytes. Proc Natl Acad Sci U S A. 1993; 90(2): 522-526, doi: 10.1073/ pnas.90.2.522, indexed in Pubmed: 7678458.

24. Geller DA, Freeswick PD, Nguyen D, et al. Differential induction of nitric oxide synthase in hepatocytes during endotoxemia and the acute-phase response. Arch Surg. 1994; 129(2): 165-171, doi: 10.1001/ archsurg.1994.01420260061008, indexed in Pubmed: 7508220.

25. Gibson JD, Pumford NR, Samokyszyn VM, et al. Mechanism of acetaminophen-induced hepatotoxicity: covalent binding versus oxidative stress. Chem Res Toxicol. 1996; 9(3): 580-585, doi: 10.1021/tx950153d, indexed in Pubmed: 8728501 .

26. Gujral JS, Farhood A, Bajt ML, et al. Neutrophils aggravate acute liver injury during obstructive cholestasis in bile duct-ligated mice. Hepatology. 2003; 38(2): 355-363, doi: 10.1053/jhep.2003.50341, indexed in Pubmed: 12883479.

27. Gujral JS, Hinson JA, Farhood A, et al. NADPH oxidase-derived oxidant stress is critical for neutrophil cytotoxicity during endotoxemia. Am J Physiol Gastrointest Liver Physiol. 2004; 287(1): G243-G252, doi: 10.1152/ajpgi.00287.2003, indexed in Pubmed: 15044177.

28. Hasegawa T, Malle E, Farhood A, et al. Generation of hypochlorite-modified proteins by neutrophils during ischemia-reperfusion injury in rat liver: attenuation by ischemic preconditioning. Am J Physiol Gastrointest Liver Physiol. 2005; 289(4): G760-G767, doi: 10.1152/ ajpgi.00141.2005, indexed in Pubmed: 15994427.

29. Hinson J, Roberts D, James L. Mechanisms of Acetaminophen-Induced Liver Necrosis. Adverse Drug Reactions. 2009: 369-405, doi: 10.1007/978-3-642-00663-0_12.

30. Houghton PJ, Zarka R, de las Heras B, et al. Fixed oil of Nigella sativa and derived thymoquinone inhibit eicosanoid generation in leukocytes and membrane lipid peroxidation. Planta Med. 1995; 61(1): 33-36, doi: 10.1055/s2006-957994, indexed in Pubmed: 7700988.

31. Hur GM, Ryu YS, Yun HY, et al. Hepatic ischemia/reperfusion in rats induces iNOS gene transcription by activation of NF-kappaB. Biochem Biophys Res Commun. 1999; 261(3): 917-922, doi: 10.1006/bbrc.1999.1143, indexed in Pubmed: 10441525.

32. Jaeschke $\mathrm{H}$, Smith $\mathrm{CW}$. Mechanisms of neutrophil-induced parenchymal cell injury. J Leukoc Biol. 1997; 61(6): 647-653, doi: 10.1002/jlb.61.6.647, indexed in Pubmed: 9201255.

33. Jaeschke H, Ho YS, Fisher MA, et al. Glutathione peroxidase-deficient mice are more susceptible to neutrophil-mediated hepatic parenchymal cell injury during endotoxemia: importance of an intracellular oxidant stress. Hepatology. 1999; 29(2): 443-450, doi: 10.1002/hep.510290222, indexed in Pubmed: 9918921.

34. Jaeschke H, McGill MR, Ramachandran A. Oxidant stress, mitochondria, and cell death mechanisms in drug-induced liver injury: lessons learned from acetaminophen hepatotoxicity. Drug Metab Rev. 2012; 44(1): 88-106, doi: 10.3109/03602532.2011.602688, indexed in $\mathrm{Pu}$ bmed: 22229890.

35. Kanter M, Coskun O, Budancamanak M. Hepatoprotective effects of Nigella sativa $L$ and Urtica dioica $L$ on lipid per- oxidation, antioxidant enzyme systems and liver enzymes in carbon tetrachloride-treated rats. World J Gastroenterol. 2005; 11(42): 6684-6688, doi: 10.3748/wjg.v11.i42.6684, indexed in Pubmed: 16425366.

36. Kehrer JP. Free radicals as mediators of tissue injury and disease. Crit Rev Toxicol. 1993; 23(1): 21-48, doi: 10.3109/10408449309104073, indexed in Pubmed: 8471159.

37. Kelly JH, Koussayer T, He DE, et al. An improved model of acetaminophen-induced fulminant hepatic failure in dogs. Hepatology. 1992; 15(2): 329-335, doi: 10.1002/ hep.1840150225, indexed in Pubmed: 1735538.

38. Kheradpezhouh E, Panjehshahin MR, Miri R, et al. Curcumin protects rats against acetaminophen-induced hepatorenal damages and shows synergistic activity with $\mathrm{N}$-acetyl cysteine. Eur J Pharmacol. 2010; 628(1-3): 274-281, doi: 10.1016/j. ejphar.2009.11.027, indexed in Pubmed: 19919835.

39. Kong LY, Li GP, Yang P, et al. Protective effect of thymoquinone on cholestatic rats with liver injury. Genet Mol Res. 2015; 14(4): 12247-12253, doi: 10.4238/2015. October.9.13, indexed in Pubmed: 26505373.

40. Kuthan $\mathrm{H}$, Ullrich V. Oxidase and oxygenase function of the microsomal cytochrome P450 monooxygenase system. Eur J Biochem. 1982; 126(3): 583-588, doi: 10.1111/j.14321033.1982.tb06820.x, indexed in Pubmed: 7140747.

41. Laskin D, Pilaro A. Potential role of activated macrophages in acetaminophen hepatotoxicity. Toxicol Appl Pharmacol. 1986; 86(2): 204-215, doi: 10.1016/0041-008x(86)90051-7.

42. Laskin D, Pilaro A, Ji S. Potential role of activated macrophages in acetaminophen hepatotoxicity. Toxicol Appl Pharmacol. 1986; 86(2): 216-226, doi: 10.1016/0041008x(86)90052-9.

43. Lawson JA, Farhood A, Hopper RD, et al. The hepatic inflammatory response after acetaminophen overdose: role of neutrophils. Toxicol Sci. 2000; 54(2): 509-516, doi: 10.1093/toxsci/54.2.509, indexed in Pubmed: 10774834.

44. Leung TM, Fung ML, Liong EC, et al. Role of nitric oxide in the regulation of fibrogenic factors in experimental liver fibrosis in mice. Histol Histopathol. 2011; 26(2): 201-211, doi: 10.14670/HH-26.201, indexed in Pubmed: 21154234.

45. Lipton SA, Choi YB, Pan ZH, et al. A redox-based mechanism for the neuroprotective and neurodestructive effects of nitric oxide and related nitroso-compounds. Nature. 1993; 364(6438): 626-632, doi: 10.1038/364626a0, indexed in Pubmed: 8394509.

46. Liu WX, Jia FL, He YY, et al. Protective effects of 5-methoxypsoralen against acetaminophen-induced hepatotoxicity in mice. World J Gastroenterol. 2012; 18(18): 2197-2202, doi: 10.3748/wjg.v18.i18.2197, indexed in Pubmed: 22611312.

47. Lu J, Holmgren A. The thioredoxin antioxidant system. Free Radic Biol Med. 2014; 66: 75-87, doi: 10.1016/j.freeradbiomed.2013.07.036, indexed in Pubmed: 23899494.

48. Maheshwari RK, Singh AK, Gaddipati J, et al. Multiple biological activities of curcumin: a short review. Life Sci. 2006; 78(18): 2081-2087, doi: 10.1016/j.Ifs.2005.12.007, indexed in Pubmed: 16413584.

49. Manov I, Motanis H, Frumin I, et al. Hepatotoxicity of anti-inflammatory and analgesic drugs: ultrastructural 
aspects. Acta Pharmacol Sin. 2006; 27(3): 259-272, doi: 10.1111/j.1745-7254.2006.00278.x, indexed in Pubmed: 16490160.

50. Manthripragada AD, Zhou EH, Budnitz DS, et al. Characterization of acetaminophen overdose-related emergency department visits and hospitalizations in the United States. Pharmacoepidemiol Drug Saf. 2011; 20(8): 819-826, doi: 10.1002/pds.2090, indexed in Pubmed: 21294217.

51. McGill MR, Yan HM, Ramachandran A, et al. HepaRG cells: a human model to study mechanisms of acetaminophen hepatotoxicity. Hepatology. 2011; 53(3): 974-982, doi: 10.1002/hep.24132, indexed in Pubmed: 21319200.

52. Michael SL, Pumford NR, Mayeux PR, et al. Pretreatment of mice with macrophage inactivators decreases acetaminophen hepatotoxicity and the formation of reactive oxygen and nitrogen species. Hepatology. 1999; 30(1): 186-195, doi: 10.1002/hep.510300104, indexed in Pubmed: 10385655

53. Mihara M, Uchiyama M. Determination of malonaldehyde precursor in tissues by thiobarbituric acid test. Anal Biochem. 1978; 86(1): 271-278, doi: 10.1016/00032697(78)90342-1, indexed in Pubmed: 655387.

54. Moshage $H$, Kok B, Huizenga JR, et al. Nitrite and nitrate determinations in plasma: a critical evaluation. Clin Chem. 1995; 41(6 Pt 1): 892-896, indexed in Pubmed: 7768008.

55. Murathanum R, Thong-Ngam D, Klaikaew N. Curcumin Prevents Indomethacin-induced Acute Gastric Mucosal Damage in Rats. Thai J Gastroenterol. 2008; 9: 118-123.

56. Muriel P. Some experimental models of liver damage. In: Hepatotoxicity: From Genomics to in vitro and in vivo Models. John Wiley \& Sons 2008: 119-137.

57. Myhre O, Andersen J, Aarnes H, et al. Evaluation of the probes $2^{\prime}, 7^{\prime}$-dichlorofluorescin diacetate, luminol, and lucigenin as indicators of reactive species formation. Biochem Pharmacol. 2003; 65(10): 1575-1582, doi: 10.1016/ s0006-2952(03)00083-2.

58. Nadaud S, Soubrier F. Molecular biology and molecular genetics of nitric oxide synthase genes. Clin Exp Hypertens. 1996; 18(2): 113-143, indexed in Pubmed: 8868997.

59. Nagi MN, Almakki HA, Sayed-Ahmed MM, et al. Thymoquinone supplementation reverses acetaminophen-induced oxidative stress, nitric oxide production and energy decline in mice liver. Food Chem Toxicol. 2010; 48(8-9): 2361-2365, doi: 10.1016/j.fct.2010.05.072, indexed in Pubmed: 20561950.

60. Negre-Salvayre A, Auge N, Ayala V, et al. Pathological aspects of lipid peroxidation. Free Radic Res. 2010; 44(10): 1125-1171, doi: 10.3109/10715762.2010.4984 78, indexed in Pubmed: 20836660.

61. Papackova Z, Heczkova M, Dankova H, et al. Silymarin prevents acetaminophen-induced hepatotoxicity in mice. PLoS One. 2018; 13(1): e0191353, doi: 10.1371/journal. pone.0191353, indexed in Pubmed: 29342206.

62. Placke ME, Ginsberg GL, Wyand DS, et al. Ultrastructural changes during acute acetaminophen-induced hepatotoxicity in the mouse: a time and dose study. Toxicol Pathol. 1987; 15(4): 431-438, doi: 10.1177/0192623387015004 07, indexed in Pubmed: 3432943.
63. Portmann B, Talbot IC, Day DW, et al. Histopathological changes in the liver following a paracetamol overdose: correlation with clinical and biochemical parameters. J Pathol. 1975; 117(3): 169-181, doi: 10.1002/path.1711170307, indexed in Pubmed: 1214189.

64. Prescott LF. Paracetamol, alcohol and the liver. Br J Clin Pharmacol. 2000; 49(4): 291-301, doi: 10.1046/j.13652125.2000.00167.x, indexed in Pubmed: 10759684.

65. Ramachandran A, Lebofsky M, Weinman SA, et al. The impact of partial manganese superoxide dismutase (SOD2)-deficiency on mitochondrial oxidant stress, DNA fragmentation and liver injury during acetaminophen hepatotoxicity. Toxicol Appl Pharmacol. 2011; 251(3): 226-233, doi: 10.1016/j.taap.2011.01.004, indexed in Pubmed: 21241727.

66. Ray SD, Mumaw VR, Raje RR, et al. Protection of acetaminophen-induced hepatocellular apoptosis and necrosis by cholesteryl hemisuccinate pretreatment. J Pharmacol Exp Ther. 1996; 279(3): 1470-1483, indexed in Pubmed: 8968373 .

67. Ruepp SU, Tonge RP, Shaw J, et al. Genomics and proteomics analysis of acetaminophen toxicity in mouse liver. Toxicol Sci. 2002; 65(1): 135-150, doi: 10.1093/ toxsci/65.1.135, indexed in Pubmed: 11752693.

68. Samuhasaneeto $S$, Thong-Ngam D, Kulaputana O, et al. Curcumin decreased oxidative stress, inhibited NF-kappaB activation, and improved liver pathology in ethanol-induced liver injury in rats. J Biomed Biotechnol. 2009; 2009: 981963, doi: 10.1155/2009/981963, indexed in Pubmed: 19606259.

69. Sevanian A, Hochstein P. Mechanisms and consequences of lipid peroxidation in biological systems. Ann Rev Nutr. 1985; 5: 365-390, doi: 10.1146/annurev. nu.05.070185.002053, indexed in Pubmed: 2992549.

70. Sintara K, Thong-Ngam D, Patumraj S, et al. Curcumin suppresses gastric NF-kappaB activation and macromolecular leakage in Helicobacter pylori-infected rats. World J Gastroenterol. 2010; 16(32): 4039-4046, doi: 10.3748/ wjg.v16.i32.4039, indexed in Pubmed: 20731017.

71. Somanawat K, Thong-Ngam D, Klaikeaw N. Effects of curcumin attenuated hepatitis in mice with paracetamol overdose. Thai J Gastroenterol. 2012; 13: 43-49.

72. Sonin NV, Garcia-Pagan JC, Nakanishi K, et al. Patterns of vasoregulatory gene expression in the liver response to ischemia/reperfusion and endotoxemia. Shock. 1999; 11(3): 175-179, indexed in Pubmed: 10188769.

73. Tayman C, Cekmez F, Kafa I, et al. Protective Effects of Nigella sativa Oil in Hyperoxia-Induced Lung Injury. Archivos de Bronconeumología (English Edition). 2013; 49(1): 15-21, doi: 10.1016/j.arbr.2012.11.003.

74. Terblanche J, Hickman R. Animal models of fulminant hepatic failure. Dig Dis Sci. 1991; 36(6): 770-774, doi: 10.1007/bf01311235, indexed in Pubmed: 2032519.

75. Tipoe GL, Leung TM, Liong $E$, et al. Inhibitors of inducible nitric oxide (NO) synthase are more effective than an NO donor in reducing carbon-tetrachloride induced acute liver injury. Histol Histopathol. 2006; 21(11): 1157-1165, doi: 10.14670/HH-21.1157, indexed in Pubmed: 16874658.

76. Wendel A, Feuerstein S. Drug-induced lipid peroxidation in mice - I. Modulation by monooxegenase activity, 
glutathione and selenium status. Biochem Pharmacol. 1981; 30(18): 2513-2520, doi: 10.1016/00062952(81)90576-1.

77. Wood ER, Berger H, Sherman PA, et al. Hepatocytes and macrophages express an identical cytokine inducible nitric oxide synthase gene. Biochem Biophys Res Commun. 1993; 191(3): 767-774, doi: 10.1006/bbrc.1993.1283, indexed in Pubmed: 7682072.

78. Wright CE, Rees DD, Moncada S. Protective and pathological roles of nitric oxide in endotoxin shock. Cardiovasc Res. 1992; 26(1): 48-57, doi: 10.1093/cvr/26.1.48, indexed in Pubmed: 1516112.

79. Xie Q, Nathan C. The high-output nitric oxide pathway: role and regulation. J Leukoc Biol. 1994; 56(5): 576-582, doi: 10.1002/jlb.56.5.576, indexed in Pubmed: 7525816.

80. Yanagida $H$, Kaibori $M$, Yamada $M$, et al. Induction of inducible nitric oxide synthase in hepatocytes isolated from rats with ischemia-reperfusion injury. Transplant Proc. 2004; 36(7): 1962-1964, doi: 10.1016/j.transproceed.2004.08.055, indexed in Pubmed: 15518712.

81. Yanagida $H$, Kaibori $M$, Yoshida $H$, et al. Hepatic ischemia/ reperfusion upregulates the susceptibility of hepatocytes to confer the induction of inducible nitric oxide synthase gene expression. Shock. 2006; 26(2): 162-168, doi: 10.1097/01.shk.0000223130.87382.73, indexed in Pubmed: 16878024.
82. Yousef MI, Omar SAM, El-Guendi MI, et al. Potential protective effects of quercetin and curcumin on paracetamol-induced histological changes, oxidative stress, impaired liver and kidney functions and haematotoxicity in rat. Food Chem Toxicol. 2010; 48(11): 3246-3261, doi: 10.1016/j. fct.2010.08.034, indexed in Pubmed: 20804811.

83. Yu L, Gengaro PE, Niederberger $M$, et al. Nitric oxide: a mediator in rat tubular hypoxia/reoxygenation injury. Proc Natl Acad Sci U S A. 1994; 91(5): 1691-1695, doi: 10.1073/ pnas.91.5.1691, indexed in Pubmed: 7510405.

84. Zhao C, Shichi H. Prevention of acetaminophen-induced cataract by a combination of diallyl disulfide and $\mathrm{N}$-acetylcysteine. J Ocul Pharmacol Ther. 1998; 14(4): 345-355, doi: 10.1089/jop.1998.14.345, indexed in Pubmed: 9715438.

85. Zhong L, Holmgren A. Essential role of selenium in the catalytic activities of mammalian thioredoxin reductase revealed by characterization of recombinant enzymes with selenocysteine mutations. J Biol Chem. 2000; 275(24): 18121-18128, doi: 10.1074/jbc.M000690200, indexed in Pubmed: 10849437.

86. Zieve L, Anderson WR, Dozeman R, et al. Acetaminophen liver injury: sequential changes in two biochemical indices of regeneration and their relationship to histologic alterations. J Lab Clin Med. 1985; 105(5): 619-624, indexed in Pubmed: 3989355. 